Origins of the Federal Reserve System 



\section{ORIGINS OF THE FEDERAL RESERVE SYSTEM}

Money, Class, and Corporate Capitalism, I890-1913

$$
\text { JAMES LIVINGSTON }
$$

Cornell University Press Ithaca and London 


\section{Copyright (C) 1986 by Cornell University}

All rights reserved. Except for brief quotations in a review, this book, or parts thereof, must not be reproduced in any form without permission in writing from the publisher. For information, address Cornell University Press, 124 Roberts Place, Ithaca, New York $1485^{\circ}$.

First published 1986 by Cornell University Press.

Second printing 1989 .

First published, Cornell Paperbacks, 1989.

International Standard Book Number o-8014-1844-5 (cloth)

International Standard Book Number o-8014-9703-5 (paper)

Library of Congress Catalog Card Number $85-48199$

Printed in the United States of America

Librarians: Library of Congress cataloging information

appears on the last page of the book.

The paper in this book is acid-free and meets the guidelines for permanence and durability of the Committee on Production Guidelines for Book Longevity of the Council on Library Resources. 
For both Patricias, once in vain, again in hope 
